\title{
Starvation and feeding with a high-carbohydrate diet induce changes in the specific activity of rat hepatic pyruvate kinase
}

\author{
Michele A. CIMBALA,* David LAU† and Joseph F. DAIGNEAULT \\ Department of Biochemistry, University of Massachusetts Medical Center, 55 Lake Avenue North, Worcester, \\ MA 01605, U.S.A.
}

(Received 19 September 1984/Accepted 26 November 1984)

\begin{abstract}
A highly specific radiosandwich assay for heptatic type-L pyruvate kinase (PK) determinants was developed. This assay was used to evaluate changes in PK specific activity which occur on starvation or feeding with a high-carbohydrate diet. Despite a large increase in both catalytic activity and immunoreactive protein, the calculated specific activity falls on feeding, and the opposite effect occurs on starvation. These change can be attributed to disproportionate changes in immunoreactive protein compared with changes in catalytic activity.
\end{abstract}

PK is an important glycolytic enzyme, which is highly regulated by hormonal signals. These signals dictate both acute directives, such as phosphorylation events (Blair et al., 1982; Ishibashi \& Cottam, 1978) and chronic changes in enzyme synthesis (James \& Blair, 1982; Munnich et al., 1984). A third mechanism, that of catalytic changes in enzyme specific activity, has also been proposed. Kohl \& Cottam (1976) first used a radioimmunoassay to detect $\mathrm{PK}$ protein and reported that, when assayed in homogenates, the specific activity of PK rose on starvation. Subsequent studies have had different results. On the basis of direct quantification of immunoprecipitated protein, Hopkirk \& Bloxham (1979) reported the opposite result, that the specific activity rose with high-carbohydrate feeding and was depressed on starvation. Parks \& Drake (1982) used a sensitive radioimmunoassay and found that insulin induced a rise in PK specific activity in the diabetic rat. However, James \& Blair (1982) found no change in the equivalence point of the antibody under different hormonal conditions.

To address the confusion in the literature, we have developed a sensitive radioassay which specifically detects as little as $250 \mathrm{pg}$ of PK protein. We have used this assay to re-examine the apparent specific activity of hepatic PK under various

Abbreviation used: PK, L-type pyruvate kinase (EC 2.7.1.40).

* To whom reprint requests should be addressed.

$\dagger$ Present address: Integrated Genetics, Framingham, MA 01701 , U.S.A. metabolic states. In contrast with more recent literature, our results agree with those of Kohl \& Cottam (1976). Our data reveal that there is a large accumulation of PK protein in the carbohydratefed rat which is almost double the increase in enzyme activity. A similar disproportionate loss of PK protein occurs on starvation, i.e. the loss of immunoreactive PK protein was greater than the loss of enzyme activity. Because of these changes, the calculated specific activity changes.

\section{Materials and methods}

\section{Animals}

Male Wistar rats weighing $175-200 \mathrm{~g}$ were maintained on a $12 \mathrm{~h}$-light $/ 12 \mathrm{~h}$-dark cycle and fed with Purina laboratory chow ab libitum, unless noted. The high-carbohydrate diet was a powder consisting of $80 \%$ sucrose and $20 \%$ chow (w/w). Starvation and re-feeding commenced about 10:00 h. Animals were killed by a blow to the head. Animals used in this study were maintained and used in accordance with recommendations in the Guide for the Care and Use of Laboratory Animals, prepared by the Institute for Laboratory Animal Resources, National Research Council (Department of Health, Education and Welfare Publication No. NIH 78-23, 1978) and guidelines of the Animal Care Advisory Committee of the University of Massachusetts Medical School.

\section{Liver preparation}

After the rat was killed, the liver was immediately placed in ice-chilled $0.9 \% \mathrm{NaCl}$ and approx. $2 \mathrm{~g}$

Vol. 226 
was removed, weighed and homogenized in $4 \mathrm{vol}$. of buffer consisting of $20 \mathrm{mM}$-Tris $/ \mathrm{HCl}, 120 \mathrm{mM}$ $\mathrm{KCl}, 5 \mathrm{~mm}-\mathrm{MgSO}_{4}, 0.1 \mathrm{~mm}-\mathrm{Na}_{2}$ EDTA, pH 7.5, at $3^{\circ} \mathrm{C}$ (Blair et al., 1976). A high-speed-supernatant fraction was prepared for assay by centrifugation of the samples for $30 \mathrm{~min}$ at $3^{\circ} \mathrm{C}$ and $150000 \mathrm{~g}$. PK activity and protein content were assayed immediately. Samples for immunoassay can be stored frozen at $-20^{\circ} \mathrm{C}$ if needed; however, assays were usually started the same day.

\section{Sandwich assay for pyruvate kinase protein}

PK antiserum (goat anti-rat PK) was treated with phenylmethanesulphonyl fluoride and partially purified by $\left(\mathrm{NH}_{4}\right)_{2} \mathrm{SO}_{4}$ precipitation (James \& Blair, 1982) and DEAE-cellulose chromatography to enrich for the IgG fraction (Reif, 1969). Antiserum IgG was further enriched for PK antibody by passage over a PK-Act-Ultrogel affinity column (LKB). Purified PK was coupled to Act-Ultrogel AcA-22 as described by the manufacturer (LKB). PK antiserum in $0.1 \mathrm{M}$ $\mathrm{Na}_{2} \mathrm{HPO}_{4} / \mathrm{NaH}_{2} \mathrm{PO}_{4}, \mathrm{pH} 7.4$, containing $0.15 \mathrm{M}$ $\mathrm{NaCl}$ was passed through the PK affinity column, which was equilibrated in the same buffer. PK antibody was eluted with $0.2 \mathrm{M}$-glycine $/ \mathrm{HCl}$, $\mathrm{pH}$ 2.8. Purified PK antibody was stored frozen $\left(-20^{\circ} \mathrm{C}\right)$ in batches at about $0.2 \mathrm{mg} / \mathrm{ml}$.

For the sandwich assay, the purified PK antibody was diluted on the day of use with $35 \mathrm{mM}$ $\mathrm{Na}_{2} \mathrm{HPO}_{4} / \mathrm{NaH}_{2} \mathrm{PO}_{4}, \mathrm{pH} 8.0$, to $20 \mu \mathrm{g} / \mathrm{ml} ; 50 \mu \mathrm{l}$ was added per well to a Falcon no. 3911 flexible micro-titre plate and the protein was allowed to bind to the plastic for $\frac{1}{2} \mathrm{~h}$ at room temperature. The antibody solution was then decanted and the plates were washed three times with distilled deionized water. Protein-binding sites were saturated by filling the wells with $3 \%(w / v)$ bovine serum albumin dissolved in $35 \mathrm{~mm}-\mathrm{Na}_{2} \mathrm{HPO}_{4} / \mathrm{NaH}_{2} \mathrm{PO}_{4}$, $\mathrm{pH} 8.0$, and the plates were left for an additional $\frac{1}{2} \mathrm{~h}$ at room temperature. The plates were decanted and washed as above.

Samples to be assayed and standards (in each experiment) were diluted in $20 \mathrm{mM}-\mathrm{Tris} / \mathrm{HCl} / 0.5 \mathrm{M}$ $\mathrm{NaCl} / 1 \%$ bovine serum albumin, $\mathrm{pH} 7.5$ (TBSA), and $10 \mu \mathrm{l}$ samples were added to wells into which had been pipetted $90 \mu \mathrm{l}$ of TBSA. Plates were then incubated overnight at $4^{\circ} \mathrm{C}$ to allow binding of enzyme and antibody. To quantify binding, plates were first rinsed five times with water as above and 130000 c.p.m. of ${ }^{131} \mathrm{I}$-anti-PK [iodinated with the lactoperoxidase-glucose oxidase Enzymobeads (Bio-Rad)] in $60 \mu \mathrm{l}$ of TBSA was added to each well. The plates were again incubated overnight at $4^{\circ} \mathrm{C}$. The plates were finally washed twice in $20 \mathrm{~mm}$-Tris/ $/ \mathrm{HCl}(\mathrm{pH} 7.5)$ containing $0.5 \mathrm{M}-\mathrm{NaCl}$ and five times in water. Wells were individually cut out and counted for radioactivity. The data for each sample are the averages of duplicate assays performed on at least two different points within the linear range of the assay.

\section{Antibody}

Antibody to PK was generously given by $\mathrm{Dr}$. James B. Blair (West Virginia University, Morgantown, WV, U.S.A.) or was prepared in our laboratory as previously described by James \& Blair (1982). Only one precipitation line was detectable on Ouchterlony plates with liver supernatant fractions.

\section{Enzyme assay}

PK was assayed spectrophotometrically at $340 \mathrm{~nm}$ as previously described (Blair et al., 1982) at saturating substrate concentrations. Protein was determined by the method of Lowry et al. (1951), with bovine serum albumin as the standard.

\section{Results}

Characterization of the radioassay for type-L pyruvate kinase

The minimum amount of PK detectable by the radioassay was $250 \mathrm{pg}$ (Fig. 1). The assay detected pyruvate kinase protein in a linear manner over a 40 -fold range, from $250 \mathrm{pg}$ to $10 \mathrm{ng}$ of protein (Fig. 1). In this range, the bound radioactivity increased 20 -fold. Above $10 \mathrm{ng}$, the response saturated and was no longer linear (Fig. 1). The assay was

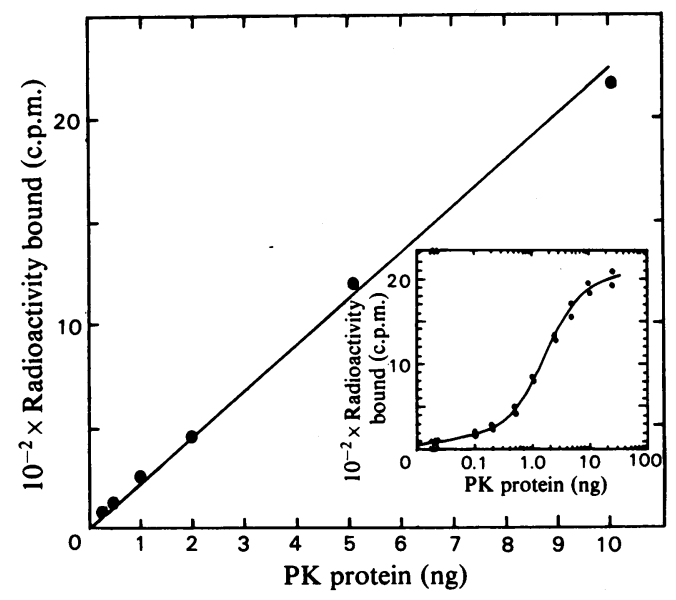

Fig. 1. Linear response of the radiosandwich assay of pyruvate kinase protein

Purified PK protein was bound to antibody in microtitre wells and detected with ${ }^{131}$ I-labelled antiPK IgG. The insert shows the response of the assay over a 300 -fold range in PK protein; data in the insert were obtained with a different preparation of ${ }^{131} \mathrm{I}$-labelled anti-PK IgG. 
specific for the L-isoenzyme. No binding occurred with supernatant fractions from spleen (which contains the $\mathbf{M}_{2}$ isoenzyme) or skeletal muscle (which contains the $M_{1}$ isoenzyme).

\section{Induction of pyruvate kinase specific activity by starvation}

Rats fed on laboratory chow contained $540 \pm 54$ munits ( 1 unit $=1 \mu \mathrm{mol} / \mathrm{min}$ ) of $\mathrm{PK} / \mathrm{mg}$ of cell protein and $2.56 \pm 0.42 \mu \mathrm{g}$ of $\mathrm{PK} / \mathrm{mg}$ of cell protein in their liver (Table 1). Starvation for only $24 \mathrm{~h}$ induced significant similar falls in both the assayable activity and immunoreactive protein. However, the loss of immunoreactive protein slightly exceeds that of assayable activity. By $48 \mathrm{~h}$ of starvation, the assayable activity has fallen by $46 \%$, but the immunoreactive-protein amounts are $60 \%$ lower than the control values. This results in a significant $(P<0.0005)$ rise in the calculated specific activity, from $227 \pm 32$ to $304 \pm 26$ munits/ $\mu \mathrm{g}$ of PK. Continued starvation for $96 \mathrm{~h}$ further depressed both the assayable activity and immunoreactive protein of the enzyme, to $177 \pm 12$ munits of $\mathrm{PK} / \mu \mathrm{g}$ of cell protein and $0.62 \pm 0.05 \mu \mathrm{g}$ of $\mathrm{PK} / \mathrm{mg}$ of cell protein respectively. However, the specific activity did not increase further, remaining at an elevated value of $285 \pm 8$ munits $/ \mu \mathrm{g}$ of PK.

Decrease in pyruvate kinase specific activity by refeeding with a high-carbohydrate diet

When rats that have been starved are re-fed with a diet containing $80 \%$ sucrose, there is a large induction of both the immunoreactive protein and the assayable activity of type-L pyruvate kinase. Re-feeding for $24 \mathrm{~h}$ after starvation for $48 \mathrm{~h}$ increased immunoreactive PK protein 6.7-fold, from $1.03 \pm 0.16$ to $6.97 \pm 0.64 \mu \mathrm{g} / \mathrm{mg}$ of cell protein. However, the assayable activity only increased 4.3fold, from $292 \pm 22$ to $1265 \pm 73$ munits $/ \mathrm{mg}$ of cell protein. This resulted in a fall in the calculated specific activity, from $304 \pm 26$ to $184 \pm 12$ munits/ $\mu \mathrm{g}$ of PK. Continued re-feeding for $48 \mathrm{~h}$ raised the assayable activity further, to $1636 \pm 47$ munits/mg of cell protein, and the immunoreactive protein to $8.79 \pm 0.65 \mu \mathrm{g}$ of $\mathrm{PK} / \mathrm{mg}$ of cell protein. However, the specific activity remained constant $(186 \pm 7$ munits $/ \mu \mathrm{g}$ of PK). A similar disproportionate rise in the immunoreactive PK protein was found in rats that had been starved for only $24 \mathrm{~h}$. Re-feeding a $24 \mathrm{~h}$-starved rat resulted in a 7 -fold increase in immunoreactive protein and only a 3.4-fold increase in assayable activity. As a consequence, the calculated specific activity falls to $134 \pm 11 \mathrm{~m}$ units $/ \mu \mathrm{g}$ of $\mathrm{PK}$. This suggests that long-term starvation is not a contributing factor to the disproportionate rise in immunoreactive PK protein.

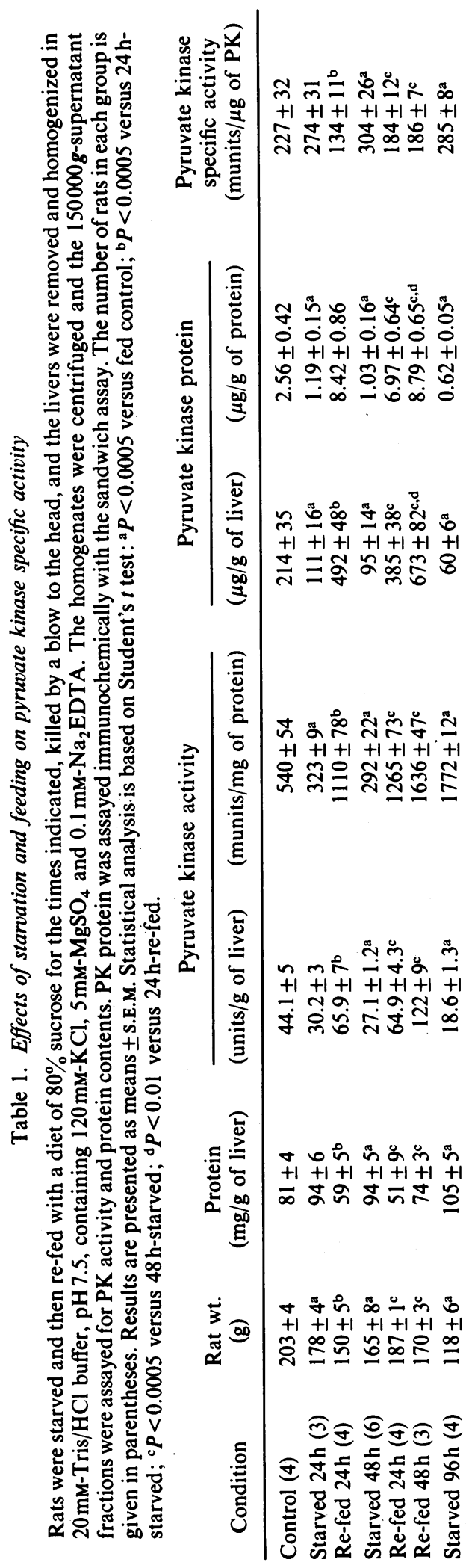




\section{Discussion}

Re-feeding a starved rat with a high-carbohydrate diet rapidly induces the transcription of PK mRNA and the synthesis of new enzyme protein (Munnich et al., 1984). Cottam and co-workers first reported that the specific activity of pyruvate kinase was increased by starvation. In their study, after $48 \mathrm{~h}$ of starvation, the calculated specific activity increased from about 50 to 100 units $/ \mathrm{mg}$ of PK (Kohl \& Cottam, 1976). Re-feeding a highcarbohydrate diet first raised and then lowered their specific activity, to 63 units/mg of PK. These authors suggested that the inherent catalytic activity of the peptide was being changed by the dietary manipulation. After that report, other data have appeared, but all with conflicting results. Hopkirk \& Bloxham (1979) reported a rise in the calculated specific activity on carbohydrate feeding, and Veneziale and co-workers found that starvation lowered the specific activity of PK in rabbits (Johnson \& Veneziale, 1980). Most recently, Parks \& Drake (1982) reported that insulin induces PK in diabetic-rat liver by a dual mechanism, part of which was to increase the specific (catalytic) activity of the protein molecule. A similar dual effect of insulin has been suggested for the induction of malic enzyme (Thompson \& Drake, 1982) and the repression of phosphoenolpyruvate carboxykinase (Veneziale et al., 1983) and fructose bisphosphatase (Hansen et al., 1982). Insulin does not affect the rate of PK degradation (Poole \& Bloxham, 1982). To examine these conflicts better, we developed a highly specific 'sandwich' radioassay for PK protein. This assay is sensitive to $250 \mathrm{pg}$ of protein (Fig. 1). Our results are the first to agree with the original observations by Cottam and co-workers, that the calculated specific activity changes in the opposite direction from that which would at first be predicted. In all cases, we attribute this result to disproportionate changes in the immunoreactive-protein amounts rather than to changes in the assayable activity. The large, 9-fold, accumulation of PK protein that we found during re-feeding is consistent with the 40-fold increase in mRNA for this enzyme reported by Kahn and co-workers (Munnich et al., 1984).

The sandwich assay reported here is much more sensitive than assays previously used to examine amounts of PK protein. For example, the radioimmunoassay used by Parks \& Drake (1982) was only sensitive to $250 \mathrm{ng}$ of protein.

Parks \& Drake (1982), in agreement with our results, found that in the insulin-treated diabetic rat the amount of pyruvate kinase protein increased 5.8-fold, whereas the activity of the enzyme only increased 2.3-fold. However, when the specific activity was calculated in those studies, the value rose compared with that found in the diabetic rat, whereas our results would have predicted the opposite trend. Although it is not clear why the directions of the specific-activity changes differ, their results may reflect the lower enzyme activities that they found. For example, in their study diabetic rats contained 4.4 units/g of liver and insulin-treated rats only contained 18 units/g of liver. In contrast, the activities in the present work range from 18.6 units/g of liver for $96 \mathrm{~h}$-starved rats to 122 units/g of liver for $48 \mathrm{~h}$ sucrose-fed animals, in agreement with the activities independently found by James \& Blair (1982).

Hopkirk \& Bloxham (1979) reported the presence of antigenically active, but catalytically inactive, protein which did not precipitate in a 30$45 \%$-satd.- $\left(\mathrm{NH}_{4}\right)_{2} \mathrm{SO}_{4}$ cut of the homogenates. They suggested that this protein may correspond to inactive proteolytic fragments of pyruvate kinase, and calculated that only $30-50 \%$ of the antigenically active protein contains full catalytic activity.

Our results do not exclude interpretations which suggest that the catalytic activity of the PK tetramer is changed under different dietary conditions. However, the large accumulation of immunoreactive protein which we find under conditions of pyruvate kinase induction may also represent an accumulation of newly synthesized, but inactive, PK protein, rather than a change in catalytic activity or an accumulation of inactive degradation products. In support of this, Marie et al. (1982) have described a form of pyruvate kinase which they call $\mathrm{L}^{\prime}$. It is a $63000 \mathrm{Da}$ precursor of the $60000 \mathrm{Da}$ type-L pyruvate kinase subunit, and its mRNA has been detected in human foetal liver mRNA by translation in vitro. It is not clear if a similar precursor exists in rat liver. Conceivably, there are two potential sites of post-translational regulation in pyruvate kinase synthesis, one site at proteolysis of an $L^{\prime}$ form to a mature $60000-\mathrm{Da}$ subunit, or a second site at assembly of the monomers $\left(\mathrm{L}\right.$ or $\left.\mathrm{L}^{\prime}\right)$ into a tetramer.

This work was supported by grant no. AM31402 from the NIH and a Basil O'Conner Starter Grant from the March of Dimes to M. A. C., who was also the recipient of a Career Development Award from the American Diabetes Association.

\section{References}

Blair, J. B., Cimbala, M. A., Foster, J. L. \& Morgan, R. A. (1976) J. Biol. Chem. 251, 3756-3762

Blair, J. B., Cimbala, M. A. \& James, M. E. (1982) J. Biol. Chem. 257, 7595-7602 
Hansen, J. B., Donofrio, J. C., Johnson, M. L. \& Veneziale, C. M. (1982) Biochim. Biophys. Acta 715, 250-253

Hopkirk, T. J. \& Bloxham, D. P. (1979) Biochem. J. 182, 383-397

Ishibashi, H. \& Cottam, G. L. (1978) J. Biol. Chem. 253, 8767-8771

James, M. E. \& Blair, J. B. (1982) Biochem. J. 204, 329338

Johnson, M. I. \& Veneziale, C. M. (1980) Biochemistry 19, 2191-2195

Kohl, E. A. \& Cottam, G. L. (1976) Arch. Biochem. Biophys. 176, 671-682

Lowry, O. H., Rosebrough, N. J., Farr, A. L. \& Randall, R. J. (1951) J. Biol. Chem. 193, 265-275
Marie, J., Simon, M.-P. \& Kahn, A. (1982) Biochim. Biophys. Acta 696, 340-344

Munnich, A., Marie, J., Reach, G., Vaulout, S., Simon, M.-P. \& Kahn, A. (1984) J. Biol. Chem. 259, 1022810231

Parks, W. C. \& Drake, R. L. (1982) Biochem. J. 208, 333337

Poole, G. P. \& Bloxham, D. P. (1982) Biochem. J. 204, 89-95

Reif, A. E. (1969) Immunochemistry 6, 723-731

Thompson, E. W. \& Drake, R. L. (1982) Biochim. Biophys. Acta 718, 224-226

Veneziale, C. M., Donofrio, J. C. \& Nishimura, H. (1983) J. Biol. Chem. 258, 14257-14262 